\title{
資料
}

\section{化学物 質の生分解性}

\section{化学物質の生分解度試験法および非イオン 界面活性剤の生分解性について}

\author{
大 場 健 吉・杉山豊 樹 \\ ライオン油脂株式会社環境衛生研究空（東京都汇F门川们平井: 7-13-12)
}

\section{The Biodegradation of Chemical Substances}

The Biodegradation Test Methods and Biodegradability of

Nonionic Surface Active Agents

Kenkichi ŌBA and Toyoki SugryamA

Lion Fat \& Oil Co. Ltd., Environmental Hygiene Laboratory

(Hirai, Edogawa-ku, Tokyo)

非イオン界面活性剂の生分解度試験法に関しては, 国 際的にみて公式に採用されている方法がない。その主た る理由は，使用されている非イオン界面活性剤が多種多 様であること, 非イオン界面活性剤の微量測定法に関し ては満足できるまでは解明されていないことにある。

しかしながら，イギリス，アメリカ，日本抢よび OECD において非イオン界面活性剈の生分解性に関し 種々検討されており, 難分解性のものについては自主規 制している国もみられる。このような状況にかんがみ, 非イオン界面活性剤の生分解性を中心にとりまとめたの で, 御参考に供したい。

\section{1 化学物質の生分解度試験法}

\section{1 生分解とは}

生分解という言葉は biodegradation を訳した言葉で あり，微生物による有機炭素化合物の分解とでも表現す べきものである。この生分解の過程を図-1 に示す ${ }^{-1)}$

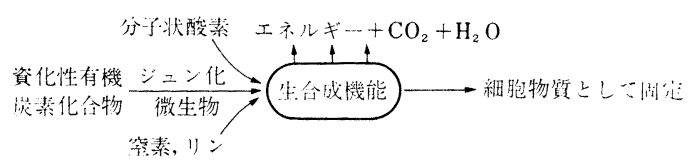

図-1 有機炭素化合物の一般的な生分解過程（好気的条件下）

すなわち，凟化性有機炭素化合物は炭素源およびエネ ルギー源としてこれら有機炭素化合物を利用しうる微生 物によって作用を受け, 分子状酸素の存在下において, 生合成機能を経て細胞物質に転化され, さらにエネルギ 一源上して利用されるときに炭酸ガスと水になる。
生分解試験を行うに際して基本上なる考え方について は次のようである2》。

(i) 第 1 次的な生分解 (primary biodegradation) 該当物質の本体をかえるに必要な最小限の生分解作 用。

（ii）環境が受け人れる程度までの生分解（environmentally acceptable biodegradation)

発ポウなど美観上の問題や水セイ生物への毒性など好 ましくない物性を示さなくなるまでの生分解作用。

(iii) 最終的な生分解 (ultimate biodegradation)

無機質までにする生分解作用。

ここで重要なことは，化合物の生分解性抢よびその代 謝最終産物は環境に及ぼす影響という点で評価されなけ ればならないことである。さらにまた有機化合物による 水質污濁を質的観点からみるならば，最終的な生分解を も考慮に入れる必要がでてこよう。

生分解性の表わし方には分解速度 (rate), 生分解度 (extent)，半減期等が用いられている。

\section{2 生分解度試験法について}

生分解度試験法には, 供試物質の微生物への暴露の過 程と供試物質の分解消失度を評価する定量分析の過程上 が含まれる。

微生物への暴露の方法を考える場合次のような要因を 考慮する必要がある。まず第一に，化学物質の生分解が 期待される場所は河川, 湖沼, 海洋など自然水系中や底 泥，士㙵中であるのか，あるいはト水处理装咱や排水处 理装狊のような人為的な系であるのかが問題となる。第 
二に, それらは好父的条件下で行われるのか, 嫌気的条 件下で行われるのかが問題となる。さらに微生物へのジ エン化方法と期間についても考慮を払わなければならな い。また試験物質濃度は, 実際に環境中に存在しうる程 度の濃度で武験を行うことが望ましく, 一般的に微量分 析の技術も必要とされることが多い。

分解消失度を評価するには，採用する定量分析によ。 て結果が異なる点に留意すべきである。すなわち，生分 解の過程でいかなる構造の化学物質が定量されているの かといら問題が大切である。

生分解度試験に用いられる分析方法は, 大別すると次 のように分類できる。

(i) 残存物質量の測定 (物理- 化学的分析法, 全有 機炭素測定法など）

(ii) 吸収 $\mathrm{O}_{2}$ 量の測定（ワールブルグ法, BOD 法, 溶存酸素测定法, クーロメータ一法など)

(iii) 発生 $\mathrm{CO}_{2}$ 鼠の測定

これらの方法の長所, 短所, 適応性, 操作上や時間的 問題点抢よび経济性について 表-1 に示す。

実験室で生分解度試験に用いられる方法には次のよう なものがある。

（i）開放（または密セン）放置法（静置法）

(ii) 振卜ウ培養法

(iii) 半連続活性污デイ法

(iv) 連続活性活デイ法

(v) ワールブルグ法

(vi) BOD 法

(vii) $\mathrm{CO}_{2}$ 測定法
これらの方法の詳細（微生物源, 接種法, 培養基, ジ ュン化, 供試物質濃度, 培養条件, 本試験法）について 界面活性郕を化学物質の一つの例として 表-2 にまとめ た。また野外試験として用いられる方法には次のような ものがある。

（i） モデル河川を用いた試験

(ii) Soil lysimeter を用いた試験

\section{2 非イオン界面活性剂の生分解性}

\section{$2 \cdot 1$ 非イオン界面活性剂の環境中（河川，下水）濃度}

河川水中あるいは下水中の非イオン界面活性剂の測定 は，使用されている非イオン界面活性剂が多種多様であ り現在のところ満足のできるまでには解明されていな い。河川水中の微量エトキシレート系非イオン界面活性

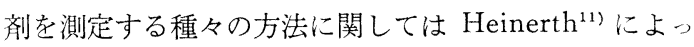
て要約されている。ここにまとめられている大部分の測 定法はエトキシレートのエーテル酸素との反応に基づい たものである。Heinerth ${ }^{11)}$ はイギリスで広く用いられ ている Patterson と Hunt の方法 ${ }^{3)}$ 将来性のある方 法として紹介している。

Patterson らの方法 ${ }^{3}$ は, $250 \mathrm{ml}$ の試料水から硫轵 マグネシウムを塩析剂としてクロロホルムで 4 [回抽仙 し，抽出したクロロホルム層を酸とアルカリで洗浄した 後溶媒を除去し, クロロホルムを溶媒として, 残分を薄 層クロマトグラフィーにより閶し，開開後のスポット を既知量のスポットと比較分析するものである。

このような方法によって 1966 年から 1971 年まで測 定されたイギリスの河川水，下水処理場放流水中の非イ

表-1 生分解度試験江用いられる分析法の特徴

\begin{tabular}{|c|c|c|c|c|}
\hline \multirow{2}{*}{ 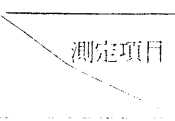 } & \multirow{2}{*}{ 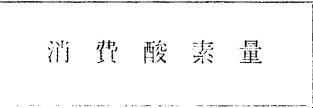 } & \multirow{2}{*}{ 発生二酸化炭素量 } & \multicolumn{2}{|l|}{ 残 存 物 } \\
\hline & & & 全有機炭 素 & 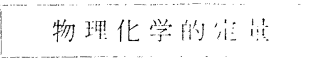 \\
\hline 荌味・们容 & 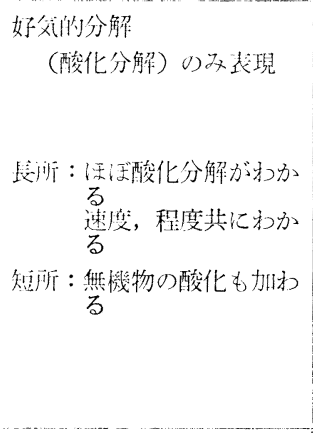 & $\begin{array}{l}\text { 好父的条件のみ } \\
\left(\begin{array}{l}\text { 嫌気的には発生メタン } \\
\text { を測定 } \\
\text { メタン } \stackrel{\text { 燃焼 }}{\longrightarrow} \mathrm{CO}_{2} \text { 測定 }\end{array}\right)\end{array}$ & 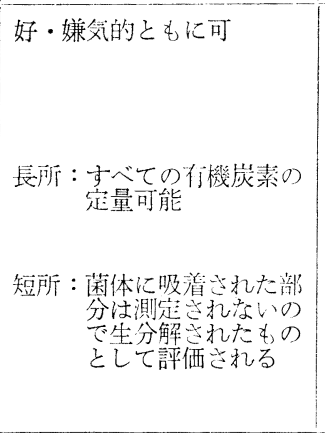 & 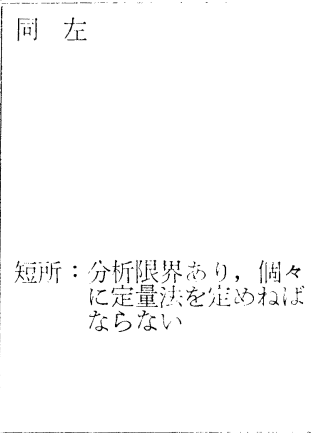 \\
\hline 邀用 性: & 油溶性:物所困難 & 油溶性物質は可能か？ & 中間生成物に適用可 一 & $\begin{array}{l}\text { 中闔生成特 } \\
\text { 場合あり }\end{array}$ \\
\hline $\begin{array}{l}\text { 操作门は公 } \\
\text { 耯性 }\end{array}$ & 簡 学 & 簡 単 & $\begin{array}{l}\text { 同一条件ですべての有機物 } \\
\text { を対象としうる }\end{array}$ & 対象物個々により異澡る \\
\hline 蜪 间] 的 & 比忟的穴期间 & 比較的長時間 & 短 時 間 & 短 時 間 \\
\hline 経 济 性: & 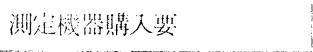 & & 測定機器購入要 & \\
\hline
\end{tabular}


表-2 界面活性斉の生分解度試験法

\begin{tabular}{|c|c|c|c|c|c|c|c|c|c|c|}
\hline & 生 物 源 & 接 種 & 培養基 & シュン(馴)化 & 洗剂濃度 & 培善条件 & 試 験 方 法 & 特 & 公定法 & 珄分解度 \\
\hline \multirow{2}{*}{$\begin{array}{l}\text { 開放放 } \\
\text { 置式 }\end{array}$} & 風乾活性污デイ & $30 \mathrm{mg}^{\prime} l$ & $\begin{array}{l}\text { BOD } \\
\text { 希积水 }\end{array}$ & な し & $10 \mathrm{ppm}$ & $\begin{array}{l}20 \pm 1^{\circ} \mathrm{CW} \\
\text { 万いかくは } \\
\text { h }\end{array}$ & 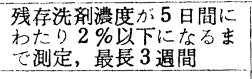 & \multirow{2}{*}{$\begin{array}{ccc}\text { 操 } & \text { 作 } & \text { 簡 } \\
\text { 単 } \\
\text { 経 } & \text { 斎 } & \text { 的 } \\
\text { 短 } & \text { 期 } & \text { 間 }\end{array}$} & $\begin{array}{c}\text { イギリ } \\
(1966)\end{array}$ & 以上 \\
\hline & $\begin{array}{l}\text { 河川水中の微生 } \\
\text { 物 }\end{array}$ & な L & 河川水 & な $L$ & 適 量 & 室 温 & 残存洗剂濃度を随時測定 & & - & - \\
\hline \multirow{3}{*}{$\begin{array}{l}\text { 振トウ } \\
\text { 培養法 }\end{array}$} & $\begin{array}{l}\text { 下水処理場の返 } \\
\text { 送污ティイ }\end{array}$ & $100 \mathrm{ml}$ & $\begin{array}{l}\text { 基脴培 } \\
\text { 養基 }\end{array}$ & $\begin{array}{l}72 \mathrm{hr} \\
\text { り返す }\end{array}$ & $30 \mathrm{ppm}$ & $\begin{array}{r}25 \pm 3^{\circ} \mathrm{C} \\
\text { 振と } 5 \\
\end{array}$ & $\begin{array}{l}7 \text { 日目と } 8 \text { 日目の生分解 } \\
\text { 度の平均をとる }\end{array}$ & \multirow{3}{*}{$\begin{array}{l}\text { 操 作 簡 単 } \\
\text { 経 済的 } \\
\text { 再現 性良好 } \\
\text { 比較的短期間 }\end{array}$} & $\begin{array}{c}\text { 日 } \text { 本4) }^{4} \\
\text { JS-K33638 } \\
(1968)\end{array}$ & \\
\hline & $\begin{array}{l}\text { 泛ン化活性污 } \\
\text { ディ天然微生物 } \\
\text { 特 殊 菌 株 }\end{array}$ & $100 \mathrm{ml}$ & " & $"$ & $30 \mathrm{ppm}$ & " & $"$ & & $\begin{array}{c}\text { アメリカ5) } \\
(1964)\end{array}$ & \\
\hline & $\begin{array}{l}\text { 士水処理場の三 } \\
\text { 坎放流水 }\end{array}$ & $0.5 \mathrm{ml} / l \mid$ & $"$ & な & $5 \mathrm{ppm}$ & $\begin{array}{l}25 \pm 1^{\circ} \mathrm{C} \\
\text { 暗所, 振之 } \\
5\end{array}$ & $\begin{array}{l}\text { 接種後 } 5 \text { 日目およ } 08 \text { 日 } \\
\text { 目か.5毎日測定，4 日間 } \\
\text { の差が } 0.15 \mathrm{mg} / l \text { 以下に } \\
\text { なるまで測定 }\end{array}$ & & $\begin{array}{c}\left.\mathrm{OECD}^{6}\right) \\
(1971)\end{array}$ & $80 \%$ 以上: \\
\hline $\begin{array}{l}\text { 半連続 } \\
\text { 活性污 } \\
\text { ディ法 }\end{array}$ & $\begin{array}{l}\text { シュン化活性污 } \\
\text { ディ天然微生物 } \\
\text { 特 殊 菌 株 }\end{array}$ & \begin{tabular}{|c|} 
MLSS \\
2,500 \\
\pm 500 \\
$\mathrm{mg} / \mathrm{l}$
\end{tabular} & 人工下水 & $\begin{array}{l}\text { MBAS を日が } \\
\text { かわることに } \\
4 \rightarrow 8 \rightarrow 12 \rightarrow 18 \rightarrow \\
20 \mathrm{mg} / l \text { と增し } \\
\text { てゆく }\end{array}$ & $20 \mathrm{ppm}$ & $\begin{array}{l}23 \mathrm{hr} \text { 暴気 } \\
\text { 後上液 } \\
\text { 交換 }\end{array}$ & $\begin{array}{l}\text { 安定期間中の } 7 \text { 日間の平 } \\
\text { 均, 連続した } 2 \text { 日間の分 } \\
\text { 解度差 } 2 \% \text { 以ののとと }\end{array}$ & $\begin{array}{l}\text { 下水処理場のモデル } \\
\text { 华, 連続よりは操 } \\
\text { 作簡単, プロセス複 } \\
\text { 程で不経済, 活性活 } \\
\text { テイ量多く吸着多い }\end{array}$ & $\begin{array}{c}\text { アメリカ5) } \\
(1964)\end{array}$ & 以上 \\
\hline \multirow{2}{*}{$\begin{array}{l}\text { 連続活 } \\
\text { 性污デ } \\
\text { 1法 }\end{array}$} & 主と菌して空中落 & $\begin{array}{c}3,000 \\
\mathrm{mg} / l\end{array}$ & $"$ & $\begin{array}{l}\text { 污デイ生成ま } \\
\text { で1週間 }\end{array}$ & $20 \mathrm{ppm}$ & \begin{tabular}{|l|} 
下水処理場 \\
の王デ化 \\
装置, 室温
\end{tabular} & $\begin{array}{l}\text { 安定期間 } 3 \text { 週間毎 } \\
\text { 分解度の平均 }\end{array}$ & \multirow{2}{*}{$\begin{array}{l}\text { 下水処理場の忠泰な } \\
\text { モデル华, 長期間を } \\
\text { 要す,管理・経済性 } \\
\text { に難点 }\end{array}$} & 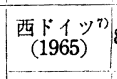 & $80 \%$ 以上 \\
\hline & 活 性 污 デ 1 & $2.5 \mathrm{~g} / l$ & $"$ & $"$ & $\begin{array}{c}20 \pm 2 \\
\text { ppm }\end{array}$ & " & $"$ & & $\underset{(1971)}{\mathrm{OECD}^{6)}}$ & $80 \%$ 以上 \\
\hline $\begin{array}{l}\text { ワール } \\
\text { フルル } \\
\text { 法8) }^{8}\end{array}$ & $\begin{array}{l}\text { 活 性 污 デ } \\
\text { ジュン化培養菌 }\end{array}$ & 適 量 & 緩衝液 & な & 適 量 & $\begin{array}{l}\text { ワールフルク } \\
\text { 検压計使用, } \\
20 \sim 25^{\circ} \mathrm{C}\end{array}$ & 酸素消費量の測定 & $\begin{array}{l}\text { 好気的分解の口 } \\
\text { 放。。 }\end{array}$ & 一 & - \\
\hline$\underset{\text { 法早 }}{\mathrm{BOD}}$ & 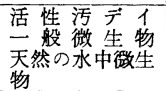 & 適 量 & $\begin{array}{l}\text { BOD } \\
\text { 希釈水 }\end{array}$ & な & 適 量 & $\begin{array}{l}\text { 密センフラ } \\
\text { スコ } 20^{\circ} \mathrm{C}\end{array}$ & $\begin{array}{l}\text { 溶存酸素消費量の測定 } \\
5 \text { 日目……어 }\end{array}$ & 好気的分解を表わ与 & - & - \\
\hline $\begin{array}{c}\mathrm{CO}_{2} \\
\text { 量测定 } \\
\text { 法10 }\end{array}$ & $\begin{array}{l}\text { 下水処理場初沈 } \\
\text { 上澄ミ液 }\end{array}$ & $\left|\begin{array}{l}150 \mathrm{ml} l \\
1,500 \mathrm{~m} l\end{array}\right|$ & BOD & あ b & $20 \mathrm{ppm}$ & 室 温 & $\begin{array}{l}\text { 試験容器か } 5 \text { の空気を } \\
\mathrm{Ba}(\mathrm{OH}) \\
\mathrm{CO}_{2} \text { を捕足する。液に通して }\end{array}$ & $\begin{array}{l}\text { 最終的生分解また測 } \\
\text { 定できる。 }\end{array}$ & - & - \\
\hline
\end{tabular}

表-3 イギリスの河川水中の陰イオン, 非イオン界面活性剤およびポリグリコールの濃度 $(\mathrm{mg} / \mathrm{l})$ (陰イオン系 : Manoxol OT として, 非イオン系 : Lissapol NX として)

\begin{tabular}{|c|c|c|c|c|c|c|c|c|c|c|c|}
\hline \multirow{3}{*}{ 年 } & \multirow{3}{*}{ 月 } & \multirow{2}{*}{\multicolumn{3}{|c|}{ Calder 川(Wakefield) }} & \multicolumn{6}{|c|}{ Aire 川 } & \multirow{2}{*}{$\begin{array}{c}\text { Don 川 } \\
\text { (Don- } \\
\text { caster) }\end{array}$} \\
\hline & & & & & \multicolumn{3}{|c|}{ Castleford 上流 } & \multicolumn{3}{|c|}{ Castleford 下流 } & \\
\hline & & 陰イオン & 非イオン & $\begin{array}{l}\text { ポリグリ } \\
\text { コール }\end{array}$ & 陰イオン & 非イオン & $\begin{array}{l}\text { ポリグリ } \\
\text { コール }\end{array}$ & 陰イオン & 非イオン & $\begin{array}{l}\text { ポリグリ } \\
\text { コール }\end{array}$ & 陰イオン \\
\hline 1966 & B. $\cdots$ & 0.75 & 0.50 & 0.13 & 0.72 & 0.40 & Tr. & 0.8 & 0.41 & 0.10 & 0.9 \\
\hline \multirow[t]{2}{*}{1967} & A. $\cdots$ & 0.97 & 0.69 & 0.36 & 0.80 & 0.51 & 0.01 & 0.7 & 0.42 & 0.07 & 0.8 \\
\hline & B. $\cdots$ & 0.97 & 0.56 & 0.42 & 0.96 & 0.49 & 0.03 & 0.7 & 0.23 & 0.05 & 0.9 \\
\hline \multirow[t]{2}{*}{1968} & A. $\cdots$ & 1.13 & 0.53 & 0.33 & 0.83 & 0.39 & 0.02 & 0.8 & 0.38 & 0.14 & 0.9 \\
\hline & B. $\cdots$ & 0.69 & 0.22 & 0.16 & 0.68 & 0.18 & 0.02 & 0.56 & 0.15 & 0.09 & 0.53 \\
\hline \multirow[t]{2}{*}{1969} & A. $\cdots$ & 0.88 & 0.38 & 0.27 & 0.76 & 0.26 & 0.03 & 0.62 & 0.20 & 0.08 & 0.63 \\
\hline & B. $\cdots$ & 1.47 & 0.72 & 0.66 & 1.16 & 0.50 & 0.08 & 0.92 & 0.40 & 0.17 & 0.67 \\
\hline \multirow[t]{2}{*}{1970} & A. $\cdots$ & 1.07 & 0.62 & 0.43 & 0.86 & 0.48 & 0.21 & 0.59 & 0.42 & 0.29 & 0.56 \\
\hline & B. $\cdots$ & 0.87 & 0.38 & 0.31 & 0.77 & 0.24 & 0.06 & 0.71 & 0.31 & 0.17 & 0.48 \\
\hline 1971 & A. $\cdots$ & 0.86 & 0.86 & 0.81 & 0.69 & 0.49 & 0.13 & 0.53 & 0.31 & 0.17 & 0.64 \\
\hline \multirow[t]{2}{*}{1969} & A. $\cdots$ & \multirow{2}{*}{\multicolumn{2}{|c|}{ 採水時の平均流量 }} & 416 & & & 525 & & & 943 & 400 \\
\hline & B. $\cdots$ & & & 219 & & & 274 & & & 493 & 173 \\
\hline \multirow[t]{2}{*}{1970} & A. $\cdots$ & & (mgd) & 334 & & & 449 & & & 738 & 493 \\
\hline & B. $\cdots$ & $(19 \mathrm{~m}$ & $=1 \mathrm{~m}^{3} / \mathrm{s}$ ) & 319 & & & 393 & & & 712 & 270 \\
\hline 1971 & A. $\cdots$ & & & 239 & & & 347 & & & 586 & 181 \\
\hline
\end{tabular}

$\mathrm{A}=1$ 月 $~ 6$ 月, $\mathrm{B}=7$ 月 12 月, $\operatorname{Tr} . \cdots \cdots$. Trace

オン界面活性剤濃度を Lissapol NX (分岐型ノニルフ エノール・エチレンオキシド（EO） $9 \mathrm{~mol}$ 付加物）の 濃度として表-3， 4 $^{12)}$ に示す。

さらに同様の方法によるテームズ川とリー川の非イオ ン界面活性剤濃度を 表-5 に示す ${ }^{13)}$ 。

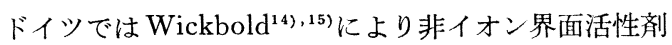
の微量分析法について新しい試みがなされている。その
操作の概要を示す。

図-2のような装置 を用いて，非イオン界 面活性剂を試験水から 酢酸エチル層に $\mathrm{N}_{2}$ ガ スを $5 \mathrm{~min}$ 吹き込むこ とにより移動させる。 その後有機溶媒層を新 しい酢酸エチルにとり 換え同様の操作を行 う。酢酸エチル層を合 一し, 必要ならばロ過, 蒸発乾固する。そして 残分を水に溶解する。 $\mathrm{pH}$ を 4 6に調製し， 改良 Dragendorffs 試 薬 $\left(\mathrm{KBiI}_{4}+\mathrm{BaCl}_{2}+\right.$ 酢酸）を加える。トウ

（橙）赤色の沈殿が形 成されるのでロ別して 取り出す。次にこの沈殿を酒石酸アンモニウム溶液に 溶解し, この中に含まれているビスマスを pyrrolidindithiocarbamate で電位差滴定することにより非イオン 界面活性剤濃度を求める。このようにして得られたドイ ツのリッペ川，ライン川の水中非イオン界偭活性剤濃度 を表-6 に示す ${ }^{15) 。 ~}$

Gerike ら ${ }^{16)}$ は, 1972 年 4 月から9 月までライン川の 
表-4 イギリ大のト水処理場放流水中の陰イオン，非イオン 界向活性剂才ふよびボリグリュールの濃度 $(\mathrm{mg} / \mathrm{l})$

\begin{tabular}{|c|c|c|c|c|c|}
\hline 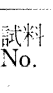 & 年月月11 & 卜水処理場 & $\begin{array}{l}\text { 陰不 } \\
\text { 㴓面 } \\
\text { 湖性 }\end{array}$ & 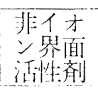 & $\begin{array}{l}\text { ホリグ } \\
\text { リコー } \\
\text { L* }^{*}\end{array}$ \\
\hline 1 & 7.10 .69 & Lund Wood & 2.6 & 0.8 & $-\cdots$ \\
\hline 2 & 8.10 .70 & Mitchell Laithes & 2.5 & 2.7 & 4.0 \\
\hline 3 & 2.10 .70 & Knostrop & 2.4 & 1.0 & 0.15 \\
\hline 4 & 17.12 .70 & Spondon & 1.7 & 0.4 & 0.1 \\
\hline 5 & 17.12 .70 & Mickleover & 1.7 & 0.6 & Tr. \\
\hline 6 & 17.12 .70 & Chellaston & 1.7 & 0.4 & Tr. \\
\hline 7 & 8.5 .69 & South & 1.5 & 0.8 & \\
\hline 8 & 5.12 .69 & Cippenham & 1.3 & 0.4 & \\
\hline 9 & 2.10 .70 & & 1.1 & 0.4 & 0.05 \\
\hline 10 & 29.7 .71 & Ham & 1.0 & 0.3 & Tr. \\
\hline 11 & 17.12 .70 & Finham & 0.9 & 0.5 & Tr. \\
\hline 12 & 3.12 .70 & Chalton & 0.9 & 0.15 & N.D ${ }^{* *}$ \\
\hline 13 & 2.10 .70 & & 0.8 & 1.2 & 0.2 \\
\hline 14 & 8. 5.69 & North & 0.8 & 0.4 & - \\
\hline 15 & 23. 9.70 & Rodbourne & 0.7 & 0.4 & $\operatorname{Tr}$. \\
\hline 16 & 7.10 .69 & Carlton & 0.7 & 0.1 & - \\
\hline 17 & 1. 4.71 & Houghside & 0.6 & 0.4 & Tr. \\
\hline 18 & 1.10 .70 & & 0.6 & 0.3 & 0.4 \\
\hline 19 & 6.10 .70 & & 0.4 & 0.1 & N.D** \\
\hline 20 & 1.12 .70 & & 0.2 & 0.4 & Tr. \\
\hline
\end{tabular}

*エチレンオキシド $3 \mathrm{~mol}$ 以l:を含む ボリチレングリコー 几型物侗

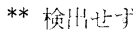

陰イオン采 : Monoxol OTとして

非イオン采: Lissapol NX として

表-5 河川水中心非イオン界面活性剂濃度

(Lissapol NX として $\mathrm{mg} / \mathrm{l}$ )

\begin{tabular}{|c|c|c|c|c|c|c|c|}
\hline & 㐿 & 1966 & 1967 & 1968 & 1969 & 1970 & 1971 \\
\hline \multirow{3}{*}{$\begin{array}{l}\text { テームズ川 } \\
\text { (Laleham) }\end{array}$} & 平均倠 & 0.018 & 0.015 & 0.018 & 0.020 & 0.021 & 0.017 \\
\hline & 最大值 & 0.03 & 0.02 & 0.03 & 0.04 & 0.05 & 0.03 \\
\hline & 最小倠 & & 0.01 & 0.01 & 0.01 & 0.01 & 0.01 \\
\hline$y-111$ & $7 x$ & 0.020 & 0.017 & 0.020 & 0.017 & 0.023 & 0.019 \\
\hline (Cingfold & 最大倠 & 0.05 & 0.03 & 0.03 & 0.03 & 0.05 & 0.04 \\
\hline Mill & 最小任 & 0.01 & 0.01 & 0.01 & 0.01 & 0.01 & 0.01 \\
\hline
\end{tabular}

MBAS 濃度，Wickbold 法による非イオン界面活性剤 濃度を調查した(表-7)。平均非イオン界面活性剂濃度は $0.036 \mathrm{mg} / l$ であり，これは陰イオン界面活性剤濃度の 約 $10 \%$ であった。測定された MBAS と非イオン界面 活性剂を仮に Na-tetrapropylene benzene sulfonate Ł nonylphenol $+\mathrm{EO} 10 \mathrm{~mol}$ 付加物として計算すれ ば，ライン川の全有機物負荷量 $(40 \mathrm{mg} \mathrm{COD} / l)$ の 2 , $3 \%$ が㓌イオン，非イオン界面活性剤由来の污濁であっ た。

一方, Brown と Hayes $5^{17}$ の微量の非イオン界面活 性戍を測定するための比色法は多くの研究者の注目を浴 びたが，感度の低さ打よびきょう雑物による妨圊が障害 上なり，收良法がいくつか提案された。

Crabb 上 Persinger $ら^{18)}$ は，試料水溶液より連続不

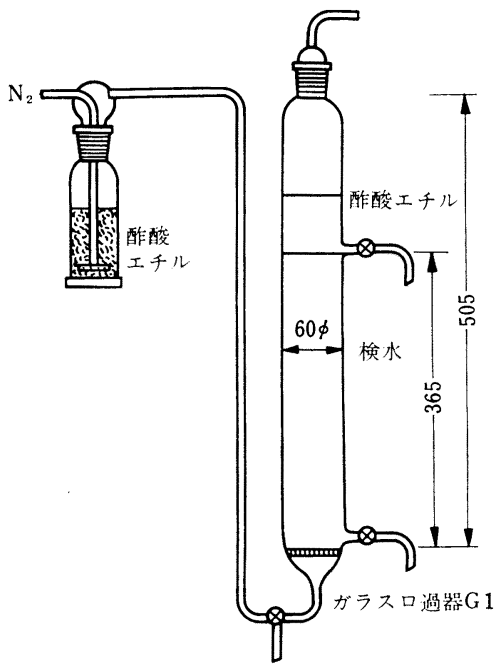

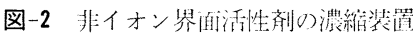

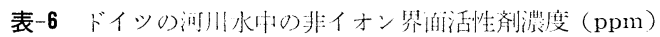

\begin{tabular}{|c|c|c|c|c|}
\hline 河川名 & 取 & 地 & 洆 & 平均推 \\
\hline \multirow{4}{*}{ リッペ川 } & \multicolumn{2}{|c|}{ Wasserwerk $\mathrm{CWH}$} & $0.019 \sim 0.019$ & 0.019 \\
\hline & \multicolumn{2}{|c|}{ Oelder Brücke } & $0.020 \sim 0.025$ & 0.023 \\
\hline & \multicolumn{2}{|c|}{ Hervest } & $0.022 \sim 0.025$ & 0.024 \\
\hline & \multicolumn{2}{|c|}{ Friedrichsfeld } & $0.014 \sim 0.017$ & 0.016 \\
\hline \multirow{3}{*}{ ライン川 } & \multicolumn{2}{|c|}{ Wesel } & $0.019 \sim 0.023$ & 0.021 \\
\hline & \multicolumn{2}{|l|}{ Rees } & $0.015 \sim 0.017$ & 0.016 \\
\hline & \multicolumn{2}{|c|}{ Emmerich } & $0.021 \sim 0.026$ & 0.024 \\
\hline
\end{tabular}

表-7 ライン川水中の MBAS, 非イオン罢面活性用湛度

\begin{tabular}{|c|c|c|c|}
\hline $\begin{array}{c}\text { 水 位 } \\
\text { (Düsseldorf) } \\
(\mathrm{cm})\end{array}$ & $\begin{array}{l}\text { MBAS } \\
(\mathrm{mg} / l)\end{array}$ & 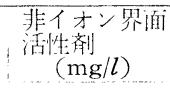 & $\begin{array}{l}\mathrm{COD} \\
(\mathrm{mg} / \mathrm{l})\end{array}$ \\
\hline 268 & 0.37 & 0.044 & 31 \\
\hline 302 & 0.31 & 0.033 & 32 \\
\hline 284 & 0.40 & 0.035 & 45 \\
\hline 268 & 0.32 & 0.035 & 43 \\
\hline 266 & 0.26 & 0.025 & 45 \\
\hline 184 & 0.45 & 0.046 & $\cdots$ \\
\hline 平均值 & 0.35 & 0.036 & 39.2 \\
\hline
\end{tabular}

油エーテル抽出により非イオン界面活性剤を濃縮した 後, 比色定量を行った。

Greff と Setzkorn ら ${ }^{19}$ はチオシアン酸コバルトアン モニウム試薬とポリオキシエチレン化合物により青色の 錯体を形成させ, この錯体を飽和塩溶液からベンゼン中 に抽出し，比色定量した。

Hey よ Jenkins $5^{20)}$ は試料水中のボリオキシエチレ ン化合物をエアー・ストリッピング法を用いて抽出し， これを分析しようとした。

大越, 秋野, 湏藤ら ${ }^{21}$ は生下水中の氺りオキシェ一レ ン系非イオン界渵活性剂を測定寸るため, 試料水 $1 l$ か ら石油エーテルで連続抽出し, エーテルを留去した後, 
水 $50 \mathrm{~m} l$ に再溶解し, Greff らの方法に従って非イオン 界面活性剂を測定し，既知濃度の試料においては $93 \%$ の回收率を得た上で，昭和 40 年 10 月の生下水中には 0.3 0.5 ppm（標準；ノニルフェノールェトキシレー 卜, $\mathrm{EO} 6 \mathrm{~mol}$ 付加）程度の存在を報告している。

\section{$2 \cdot 2$ 各国における非イオン界面活性剂 の生分解度試} 験法

非イオン界面活性剤の生分解度試験法は国際的にみて も公定法として公式に採用されている方法はないが，現 在までにイギリス，アメリカ，日本，OECD で行われ た検討状況は次のようである。

イギリスにおいては 1966 年に官氏合同の公的機関で ある合成洗剤技術委員会 (Standing Technical Committee on Synthetic Detergents) が, リバー・ダイ ・アウェイ法の改良法を陰イオン界面活性剂の生分解度 測定法に採用した。この第 8 次の年次報告 ${ }^{3}$ の中には, 溶媒抽出を行った後薄層クロマトグラフィー法で分析す ることにより，ポリオキシエチレン系非イオン界面活 性剤定量一の適応性を検討している。さらにPatterson $ら^{222,23)}$ は，アルコールポリエトキシレートおよびアル キルフェノールポリエトキシレート系の非イオン界面活 性剂の生分解度を薄層クロマトグラフィーおよび発ポウ 試験を分析手段として検討し，分解のどの段階でも発ポ ウ性は薄層クロマトグラフィーからえられた結果とよく 一致することを見いだした。

アメリカセッケン洗剤協会 (SDA) は, 1965 年に陰 イオン界面活性剂である ABS/LAS の生分解度試験法 を定めた5゙。それに引き続き, 家庭用・工業用洗剂の成 分として量的にはわずかながら使用されている非イオン 界面活性剤についてもその生分解度試験法の検討が行わ れてきている。

1969 年には過去 3 力年にわたる SDA の生分解に関 する専門小委員会の非イオン界面活性剤の生分解度試験 法の検討状況を要約した中間報告 ${ }^{2}$ が出された。委員会 は生分解性の基本を, 環境に受け入れられるまでの生分 解すなわち, “生分解性の主たる関心は排水処理設備に おける処理の叮能性という点におかれるが，大気，土， 水という環境に対して完全に受け入れられるような物質 になるといらこと”においている。

第一次の検討段階において考虑の払われた各種の生分 解度試験法としては, 振とうフラスコ法, 半連続活性污 デイ法, バンチ・チャンバー (Bunch-chamber) 法およ びリバー・ダイ・アウェイ (River Die Away) 法があ る。しかし, 再現性が高いこと, 野外試験結果との相関 性より半連続活性活デイ法が注目され, 第一次から第三 次までの三段階に分けて半連続, 活性污デイ法の適用叮 能性が検討された

第 4 回合同実験の結果より, $23 \mathrm{hr}$ 基気後 $1 \mathrm{hr}$ 静置.
により培養液の交換を行い，SS 濃度: 2500( \pm 500$)$ $\mathrm{mg} / l$, 界面活性剂濃度 $20 \mathrm{mg} / l$, 人丁.下水 (グルコース $300 \mathrm{mg} / l$, ポリペプトンブロス $200 \mathrm{mg} / l, \mathrm{~K}_{2} \mathrm{HPO}_{4} 130$ $\mathrm{mg} / l)$ が採用され, 污デイは都市下水処理場から採取し たものとし，期間は 32 日以内といら条件で評価されて いる。検討された分析方法としてコバルトチオシアネー トによる比色法, デ・又イ表两張力剂なじの表面張力低 下能変化の測定法, および発ポウ性の試験などがある。 その結果，アワをたてその舅を定量して生分解度評価の 尺度とする方法がまず叮能性のあるものであった。比色 法は発ポウ性, 表面張力との相関性に欠け, 表面張力測 定はきょう雑物が再現性のある結果を妨害する点で利用 しえないものであった。しかし，アワの量を測定して生 分解度を評価することにも, 分析者が異なるとばらつき が大きいという問題がみられた。最後の合同実験で採択 された半連続活性污デイ法は最終的な決定ではないが高 い再現性と野外試験結果との相関性より非イオン界面活 性剂の生分解性の良否を判断するにはまず満足できるも のと考えられている。

日本においいて陰イオン界面活性剤を適用範囲とした 日本工業規格 JIS K-3363(1968) を制定 $\left.{ }^{4}\right)$ の際，今後の 検討課題として非イオン界面活性剂の生分解度試験法が 残された。油化学協会内に設けられた合成洗済生分解度 判定小委員会では検討を開始するに当たり，生分解の意 味を環境に好ましくない影響を与えないまでの分解除去 (Foam pollution の消失) に抢き，嘼面活性を消失す る程度を目安として，3 研究機関を中心として合同実験 を行い，1971 年に中間報告 ${ }^{24)}$ を出した。この合同実験 においては, 微生物への暴露方法として, 前述の日本工 業規格に準じる振とうフラスコ法とアメリカの SDA で 高い評価の与えられた半連続活性污デイ法を用い，分析 法はコバルトチオシアネート法による比色分析上アワ量 測定を行い，非イオン界面活性剂のなかでも代表的なポ リオキシエチレン系界面活性剂やアルカノールアミドを 中心として生分解度試験法の検討を行った。これらの塞 験において振とうフラスコ法による測定結果は各実験機 関ともほぼ一致し，比色分析法とアワ容荲測定法の両評 価法ともに近い值をえた。しかし, 半連続活性污デイ法 による測定結果では実験機関の䦎で差が大きいなど難点 がみられた。

ちなみに, 油化学協会では非イオン界面活性剂生分解 度試験法に関する日本工業規格作製の委託を受け, 上述 の結果を基礎にして, 活性污デイを試験に供する非イオ ン界面活性剂でジュン化した後, 振卜ウ培養しその生分 解度をコバルトチオシアネート法もしくはアワ量测定で 分析する日本工業規格原案をましめている。

OECD に招いては 1971 年にに国際的に受け人れられた 陰イオン界面活性剂生分解度試験法が公けにされた 
あわせてこの報告のなかで，非イオン界泊活性剂の生分 解試験法の必要性が指摘された。その後 OECD は， 3 回の協同 Ring test t行っている。この試験に参加 しているドイツやスイスの研究では Wickbold の方法 在広く使っており，イギリスでは Wickbold ${ }^{14), 15) ~ や ~}$ Patterson $5^{3)}$ の方法を検封している。2回の Ring test の後, 非イオン界面活性剂の生分解試験方法を検討 する新しい Expert group が 1972 代：6月に設立され た。1973 年: 1 月にその group の第 1 回公式会議が開催 され，分析方法が討議された。始めにWickbold 法を評 価するために 3 種のノニルフェノールエトキシレートを 使って行われた実験よりエチレンオキシド (EO) 6 $\mathrm{mol}$ 付加程度の場合に抵出操作の改良が望まれるが，総 括的な結論においてはWickbold 法は今後さらに検討， 標淮化してゆく洒偪をもつ方法であることが認められ た。次回の合同試験は第一アルコールエトキシレートに ついて行われる予定である。しかし，現在のところ group は微生物一の暴露方法については検討を行ってい ない。

その他非イオン界诣活性剤に関するヨーロッパの状沉 上して, スウェーデンでは 1973 年以降ハード型のノニ ルフェノールエトキシレート（EO $5 \mathrm{~mol}$ 付加以上）を 自主規制している。EC では非イオン界偭活性剤の生分 解度試験法を 1976 年までに作製するというタイムスケ ジュールが発表されている。

\section{3 代表的な非イオン界面活性剂の生分解機序}

$2 \cdot 3 \cdot 1$ 置換基のないグリコール, ポリグリコール

酢酸菌 Gluconobacter や Acetobacter によるグリコ ールやポリグリコールの酸化に関する総説の中で De Ley ${ }^{25)}$ はエチレングリコールはグリコール酸 HOCCO$\mathrm{OH}$ 一転換し，上きにはシュウ酸 $\mathrm{HOOCCOOH}$ まで変 化するとしている。ジェチレングリコールも, 速度は遅い が同様な経路で $\mathrm{HOCCOCCOOH}$ や $\mathrm{HOOCCOCCOOH}$ を生ずることを報告した。またトリエチレングリコール もさらに避くなるが，同じような経路をたどるとしてい る。

Abeles ${ }^{26)}$ は, Aerobacter aerogenes を嫌気的にグリ セリンで生育させた後, 無細胞抽出液を調製し, プロピ レングリコールをプロピオンアルデヒドに，エチレング リコールをアセトアルデヒドに転換することを見いだし た。

このようにボリグリコールの好気的生分解における第 一段階は末端 $-\mathrm{CH}_{2} \mathrm{OH}$ がアルデヒドさらにはカルボキ シルに酸化されることであろうと考えられる。しかし， 次の段階における機構, 特にエーテル結合の切断につい て詳細はまだ明らかにされていない。

$2 \cdot 3 \cdot 2$ アルコールエトキシレート

值鎖第一アルコールエトキシレート (LPAE) の生分
解は，もとの型を急速に消失して分子中のエトキシレー ト部分をポリエチレングリコールのよらな型で遊離す る。LPAE の場合, このような加水分解とアルキル鎖 の酸化分解が考えられる ${ }^{27) 。}$

Frazee と Osburn ${ }^{28)}$ は, 直鎖テトラデシルアルコー ルエトキシレート（EO $8.3 \mathrm{~mol}$ 付加）を河川水中で分 解させ, アワ・ストリッピング法により残存している界 面活性剂を単離して赤外線吸収スベクトル法で分析し た。 5 日目に界面活性剂含量は 0 を示し, 溶液は起ホウ 性を示さなかった。そしてクロロホルム抽出によ一てア ルキル鎖のないポリエチレングリコール $\mathrm{E}_{x}$ 在約 5.7

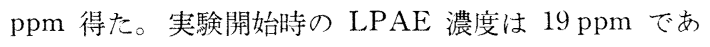
り, EO $8.3 \mathrm{~mol}$ としては約 $13 \mathrm{ppm}$ に相当する。この ことから疎水基が最初に分解し, ボリグリコール在残存 させ,これも徐々に分解したことを示した。

Patterson ら ${ }^{29)}$ は薄層クロマトグラフィーを用いて 分解機序の検討を行い, アルコールエトキシレートの 場合には，（i）疎水部と親水部への分子の開裂，（ii） 柾水基の急速な酸化，の二つの経路があり，これらが同 時に進行していると考えている。Patterson らは，300 $\mathrm{mg} / l$ のセチル・ステアリルエトキシレート (EO $9 \mathrm{~mol}$ 付加）を同量の乾燥污デイを用いて分解を行い, 薄層ク ロマトグラフィーで調ベた出発物質濃度は 2 週間後に $10 \mathrm{mg} / l$ に落ちていた。このときのクロロホルム抽出物 在薄層クロマトグラフィーで分離した。薄層プレートの 中心のバンドをかきとり溶媒抽出を行い, 抽出物をさら にメチルエチルケトン (MEK) 一水分配法で極性の差に よる分離を行った。MEK 画分, 水画分に含まれる物質 の分離を薄層クロマトグラフィーで行い, 分別された物 質の赤外線吸収スペクトル， NMR スペクトルを調ベ た。水画分からは分子量約 400 のボリグリコールタイプ の物質を得, これは朘化を示すカルボニル基を含んでい た。アルキル基物質はみられなかった。MEK 画分には もとの非イオン界酒活性剤由来の物質であるが，アルキ ル部とエトキシル部の割合が末分解のものに比べより大 きい，カルボニル基をもったエトキシレートを含んでい た。 3 週間後に水画分に現れた物質の赤外線吸収スぺ クトルから, カルボニル基に対してエトキシル部の割合 はさらに低くなっていることが明らかになった。この ことはアルキル基とエトキシル基の間に加水分解開裂が 生じたことを示している。また，七チル・ステアリルエ トキシレート（EO $9 \mathrm{~mol}$ 付加）を同様に分解させ, 通 常のクロロホルム抭出を行った後, 液を腰性にして再び クロロホルム抽出を行った。抽出物を MEK-水分配法 で分離した後, 薄層クロマトグラフィーにより分析し た。水画分にはエトキシル基を含む物筫が存在し，これ はもとの非イオン界面活性剂よりも㢦性の大きい物貿 で, 生成してから完全に消失するまで連続して愬められ 
た。赤外線吸収スペクトルから，カルボニル基とエトキ シル基を含み, NMR スペクトルより 1 個のメチレン基 はカルボキシル基に対してい位にあることを示した。

Nooi ら $^{30}$ は ${ }^{14} \mathrm{C}$-標識ステアリルアルコール EO 付 加物 6 種を用い，バッチ式活性污デイ法により ${ }^{14} \mathrm{CO}_{2}$ の生成, ${ }^{14} \mathrm{C}$ の液中分布, および污デイへの ${ }^{14} \mathrm{C}$ の結合 よりそれらの生分解機序を調べた。まずはじめに, 非イ オン界面活性剤は $\mathrm{CO}_{2}$ の生成のほとんどないまま污デ イに吸着し, ついでアルキル鎖から分解する。この過程 は大半のアルキル鎖が分解されると止まる。こうして生 じた親水性の分解生成物は污デイから離れ，しばらくの 後急速に分解される。また, $\mathrm{EO}$ 鎖が長くなると $\mathrm{EO}$ 鎖 の分解自体と同じくアルキル鎖の分解も遅くなることが わかった。

$2 \cdot 3 \cdot 3$ アルキルフェノールエトキシレート

アルキルフェノールェトキシレートの生分解過程 ${ }^{27)}$ 中で最も著しいのは $\mathrm{EO}$ 鎖の短鎖化である。多分 $\mathrm{EO}$ 鎖は疎水基についたまま, EO を一個ずつ短くしてゆく ものと考えられている。そして末端のグリコールの-OH は，いずれの段階でもそのままで残されている。

$\mathrm{R} \phi \mathrm{OE}_{n} \mathrm{OCCOH} \rightarrow \mathrm{R} \phi \mathrm{OE}_{n}+\mathrm{HOCCOH} \rightarrow \mathrm{HOCCOOH}$ 短鎖化は純粋に加水分解によるものであり，エチレン グリコールを生じ, これは引き続いて酸化されてゆくも の上考えられる。一方, 疎水基末端においても酸化が起 こり， $\omega$ 一酸化さらには構造的に可能ならば $\beta$-酸化入入 ってゆくと考えられる。

アルキルフェノールェトキシレートの生分解過程は, Frazee と Osburn ら ${ }^{28)}$ やさらには Osburn や Benedict $ら^{31}$ により赤外線吸収スペクトル, 紫外線吸収スペクト ル法により詳しく調べられた。赤外線吸収スペクトル法 においては, 脂肪族エーテルによる $1120 \mathrm{~cm}^{-1}$ の吸収と 芳香族エーテルによる $1250 \mathrm{~cm}^{-1}$ の吸収を調べることか ら EO 濃度の測定を行うものである。Osburn らはこれ らの分析方法を直接河川水溶液に用いることができない ので単離, 濃縮の手段として次の方法をとった。

（i）アワストリッピングを行って界面活性物質を分 離し界面活性を失った物質を残存させる。

(ii) 中性もしくはアルカリ性でクロロホルム抽出を 行う。

（iii）強酸性化した後, 再びクロロホルム抽出し, カ ルボキシル化合物をとり出す。

(iv) ときにはイオン交換樹脂処理を行い，イオン性 のカルボキシルその他中間物質を除いた後, 非イオン性 の物質を活性炭に吸着させる。

Frazee と Osburn ら ${ }^{28), 30)}$ は分岐型ノニルフェノール エトキシレート（EO１１） mol付加）在河川水で 34 日間 生分解させ, その生分解の過程を前述の分離・分析法老 用いて次のように報告している。試験期間の第 2 週から
第 3 週の間にエチレンオキシドはかなりの分解を示し た。0日目と 34 日目の残存界面活性剂の赤外線吸収ス ペクトルの分析から明らかにエトキシル基に減少がみら れた。34 日目に得られた抽出物はノニルフェノールェ トキシレート（EO $4 \mathrm{~mol}$ 付加）と同じスペクトルを示 した。ノニルフェノールエトキシレート (EO $4 \mathrm{~mol}$ 付 加）を河川水で分解させると，10日目にアワストリッ ピング法で単離した界面活性剤は赤外線吸収スペクトル でカルボニル領域に吸収を示さなかったが，クロロホル 厶抽出物は明らかに $1700 \mathrm{~cm}^{-1}$ に吸收を示した。34 日 目には起ホウ性を示さず全界面活性能を失ったが，ク口 ロホルム抽出物濃度は最初の濃度の約 $60 \%$ を示した。 一方, 強酸性にしてクロロホルム抽出すると最初の濃度 の $75 \%$ が抽出されこれは強いカルボニルの吸収を示し た。

Patterson ら ${ }^{29}$ は, アルキルフェノールエトキシレー トの最も通常の分解経路をアルキル基, 芳香環, エトキ シ鎖のゆっくりした酸化と加水分解が同時に起きること としている。分枝型ノニルフェノールエトキシレート (EO $9 \mathrm{~mol}$ 付加) $20 \mathrm{mg} / \mathrm{l}$ を乾燥污デイ $100 \mathrm{mg} / l, \mathrm{pH} 7$ で分解させ 6 週間目に薄層クロマトグラフィーで分析し て $9 \mathrm{mg} / \mathrm{l}$ まで分解させた。

分解物の薄層クロマトグラムによればスポットのパタ ーンはそのままで，その $R_{f}$ 值をやや下げていた。この ことはアルコールエトキシレートのような開裂のないこ 上を示すものである。通常のクロロホルム抽出後, 液を 酸性にして再抽出してもエトキシレートは見いだせなか った。そこで, より極性の分解物を分離するためにアル ミナカムラ法を用い, まず $\mathrm{CHCl}_{3}-\mathrm{EtOH}-\mathrm{H}_{2} \mathrm{O}(50$ : $47.5: 2.5 \mathrm{vol} / \mathrm{vol})$ で溶出し, 次いで割合を(50:42.5 : $7.5 \mathrm{vol} / \mathrm{vol})$ にかえ 2 番目の溶出を行った。6 週間分 解させた場合, アルミナカラムの1番目の溶出液中には かなりエトキジ鎖長を短くしたエトキシレートのみを微 量含んでいた。 2 番目の溶出液中に含まれていた物質は 著しく芳香族の吸収が少なく, 強いカルボニルとカルボ キシルの吸収を示した。これはアルキル基末端への攻撃 とエトキシ鎖のゆっくりした加水分解から生じた極性物 質の存在を示している。Patterson らはアルキルフェノ 一ルエトキシレートとアルコールエトキシレートの初期 経路の差異を芳香環と急速な酸化に抵抗性を示す分枝型 のアルキル基の存在によるものと考えている。

浅原ら ${ }^{24}$ はノニルフェノールェトキシレートを活性污 デイを微生物源として振とらフラスコ法で 5 日間生分解 させ, コバルトチオシアネート法による分析で生分解度 98.2\% を示したとき, 培養液をクロロホルム抽出した。 抽出物をガスクロマトグラフィーで分析すると図-3の 上らなクロマトグラムを示した。すなわち，エチレンオ キシド $2 \mathrm{~mol}$ 付加物に代表される低エチレンオキシド 


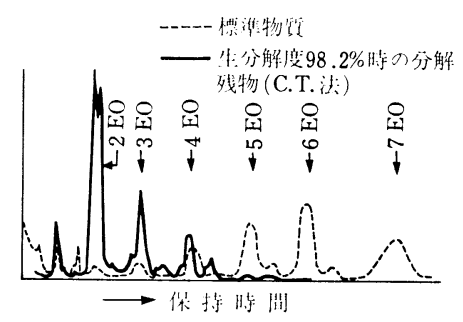

図-3ノニルフェノールェトキシレートの ガスクロマトグラム

付加物が多星に検出され, 出発物質に比較してエチレン オキシド鎖が短くなっていることが確認された。

\section{4 非イオン界面活性剂生分解度試験法の問題点}

非イオン界面活性剂の生分解度試験方法は国際的にみ て，いまだ公式に採用されているものがない。その拉も 决技術上の問題点としては，第一に非イオン界面活性剂 は構造上多種多様であり分析法の制定が困難であること である。すなわち、このように幅広い化合物に適用しう る分析法を確立することが極めて困難なところに大きな 問題がある。第二に，ある定量法で評価される生分解の 程度とそれに伴う分子構造の質的変化との関係が一義的 につながり難いなどの難点があげられる。

Mausner $ら^{2)}$ も非 イオン界面活性剂の微生物分解性 の試験に関して標準の実験室的方法を確立する場合に同 じことを指摘している。

以上のように困難は多いが，しかし生分解度試験法を 開発するため新しい試みもなされている。

Sturm ら ${ }^{10)}$ は，分解性のスクリーニング試験を $\mathrm{CO}_{2}$ 発生試験法を用いて検討した。この方法の長所は第 1 に 非常に多くの有機物質の迅速なスクリーニング法として 特別な分析技術を確立しなくてよい点である。第 2 に第 一次の分解よりもむしろ最終的な分解の速度と分解度を 予備的に判断することができることである。さらにこの 方法は, 非イオン界而活性剤の微生物分解をみる場合 沉，広い範囲の条件下で行うことができ容易に条件をか えて実施しうることである。この基本的な試験は, 嫌 気的条件, 低温, 限られた恔素条件（微好気的）および ${ }^{14} \mathrm{C}$ でラベルした物質を用いて分解の機序を決定する試 験法に改良が行われている。

本稿は, 山本油化学協会荓西支激主㑷の符 30 回界面化学部会 (昭和 48 年 11 月 27 月) にて講演したものである。

(畍和 48 年 11 月 1 日受理)

\section{文献}

1) C.A. Vath, Soap Chem. Spec., 40 (2), 56, 182 (1964)

2) M. Mausner, J.H. Benedict, J. Amer. Oil Chem. Soc., 46, 432 (1969)

3) Ministry of Housing and Local Government, "Eighth
Progress Report of the Standing Technical Committee on Synthetic Detergents", Her Majesty's Stationery Office, (1966), London

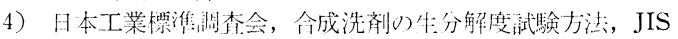
K 3363-1968

5) The Subcommittee on Biodegradation Test Method of the SDA. J. Amer. Oil Chem Soc., 42, 986 (1965)

6) OECD Expert Group on Biodegradability of Synthetic Detergent, "Determination of The Biodegradability of Anionic Synthetic Surface Active Agents" (1971)

7) Bundesgesetz Blatt, Teil No. 49, s. 698, Verordnung über die Abbaubarkeit von Detergentien in Waschund Reinigungsmitteln, (1962), Bonn

8）日本化学会編, 実験化学講座 24 , 牛物化学 II, p. 85 , 丸 普, 東京

9）日木工業標準調榃会, 工場排水試験方法, JIS K 01021971

10) R.N. Sturm, J. Amer. Oil Chem. Soc., 50, 159 (1973)

11) E. Heinerth, Tenside, 3, 109 (1966)

12) Depertment of the Environment, "Thirteenth Progress Report of the Standing Technical Committee on Synthetic Detergents", Her Majesty's Stationery Office, (1972), London

13) Department of the Environment, "Fourteenth Progress Report of the Standing Technical Committee on Synthetic Detergents", Her Majesty's Stationery Office, (1973), London

14) R. Wickbold, Tenside, 8, 61 (1971)

15) R. Wickbold, Tenside, 9, 173 (1972)

16) P. Gerike, R. Schmid, Tenside, 10, 186 (1973)

17) E. Brown, T.J. Hayes, Analyst, 87, 755 (1955)

18) N.T. Crabb, H.E. Persinger, J. Amer. Oil Chem. Soc., 41, 752 (1964)

19) R.A. Greff, E.A. Setzkorn, J. Amer. Oil Chem. Soc., 42, 180 (1965)

20) A.E. Hey, S.H. Jenkins, Water Research, 3, 887 (1969)

21）大越, 秋野, 須藤, 用水之廃水，8，220（1966）

22) S.J. Patterson, C.C. Scott, J. Amer. Oil Chem. Soc., 44, 407 (1967)

23) S.J. Patterson, C.C. Scott, J. Amer. Oil Chem. Soc., 45, 528 (1968)

24) 浅原, 関口ら, 油化学, 21, 33 (1972)

25) J. De Ley, K. Kersters, Bacteriolgoical Reviews, 28, 164 (1964)

26) R.H. Abeles, H.A. Lee Jr., J. Biol. Chem., 236, pc 1 (1961)

27) R.D. Swisher, "Surfactant Biodegradation", Marcel Dekker Inc., (1970), New York

28) C.D. Frazee, Q.W. Osburn, J. Amer. Oil Chem. Soc., 41, 808 (1964)

29) S.J. Patterson, C.C. Scott, J. Amer. Oil Chem. Soc., 47, 37 (1970)

30) J.R. Nooi, M.C. Testa, Tenside, 7, 61 (1970)

31) Q.W. Osburn, J.H. Benedict, J. Amer. Oil Chem. Soc., 43, 141 (1966) 